\title{
Evaluation of Seed and Fruit Powders of Capsicum annum and Capsicum frutescens for Control of Callosobruchus maculatus (F.) in Stored Cowpea and Sitophilus zeamais (Motsch) in Stored Maize
}

\author{
M. O. Oni (Corresponding Author) \\ Department of Biology \\ Adeyemi College of Education Ondo, Nigeria \\ P. M. B. 520, Ondo, Ondo State, Nigeria.
}

Tel: 8-03-430-0943Ｅ-mail: mercyyinka2007@yahoo.co.uk

Received: September 03, 2010 Accepted: September 14, 2010 doi:10.5539/ijb.v3n2p185

\begin{abstract}
Capsicum annum and Capsicum frutescens fruit and seed powders were evaluated in the laboratory for the control of Callosobruchus maculatus (F.) in stored cowpea and Sitophilus zeamais Motschulsky in stored maize. Capsicum frutescens seed powder and Capsicum annum seed powder dust were toxic to C. maculatus and $\mathrm{S}$.zeamais at the rate of $5.0 \mathrm{~g}, 7.5 \mathrm{~g}$ and $5.0 \mathrm{~g}$, per $50 \mathrm{~g}$ cowpea and $50 \mathrm{~g}$ maize within $48 \mathrm{hrs}$ and $96 \mathrm{hrs}$ respectively. This paper highlights the potential of $\mathrm{C}$. frutescens and C. annum seed powders as seed protectants against the test bruhids at higher rates, than their ineffective fruit powders in all parameters assessed.
\end{abstract}

Keywords: Capsicum annum, Capsicum frutescens, Seed powder, Fruit powder, Mortality, Callosobruchus maculatus, Sitophilus zeamais

\section{Introduction}

Cowpea, Vigna unguiculata (L) Walp and maize, ( Zea mays L.) are major dietary staple foods (Ofuya, 2001:Ofuya and Adedire, 2004). Cowpea amounts to $60 \%$ daily dietary protein intake of most Nigerians (Oparaeke and Dike, 1998), while maize provide families with much needed nutrients, such as carbohydrates, proteins, fats, vitamin B and minerals (Ashamo, 2007 : Kling and Edmeades, 1997). 100\% damage has been reported on unprotected cowpea after 3-5 months storage (Singh, 1997), by Callosobruchus maculatus (F.). Maize has also been reported in the tropics to be heavily infested by various pests, majorly Sitophilus zeamais Motschulsky, with about 30-50\% damage after 6 months in storage (Taylor, 1971). Synthetic insecticides employed in the control of insects pests proved effective, very expensive, unavailable at critical periods and they sometimes constitute health hazards to consumers (Adedire 2001: Ofuya, 2001: Oparaeke et al., 1998: Lale, 2002 ).This necessitates continous research towards substitution of harzadous synthetic insecticides for use of cheaper and eco-friendly natural plant products with active safe components, among which are use of powdered plant parts, oils and extracts.

However, the use of these synthetic chemicals is also hampered by many attendant problems such as development of insect resistant strains, their toxic residues getting into food of animals and man, workers safety and high cost of procurement ( Sighamony et al.,1990 ).Literature from Nigeria and other West African countries revealed Eugenia aromatica, African brown pepper, Piper guineense, Allium sativum, Pepper derivatives ( $\mathrm{Su}$, 1994; Lale, 1992; Onu and Aliyu, 1995; Ashamo, 2007; Oni 2009; Adedire and Lajide, 2001: Ofuya et al,. 2000: Ogunwolu, and Odunlami 1996;Ivbijaro and Agbaje,1986) as safe, affordable and effective natural plant products with some degree of medicinal and insecticidal properties. This paper highlights the results of investigation on three application rates of Capsicum annum Miller and Capsicum frutscens L. fruit and seed powders in the control of C. maculatus in stored cowpea and S. zeamais in stored maize.

\section{Materials and Methods}

\subsection{Rearing of insect pests}

Adult cowpea storage beetles, Callosobruchus maculatus and maize weevils, Sitophilus zeamais were cultured in No.l kilner jars with meshed lids in Crop, Soil and Pest Management Department of Federal University of Technology Akure, Ondo state, Nigeria in open laboratory through-out the period of research. Standard procedure for culturing seed beetles, Ofuya and Creland, 1995: Olotuah et al., 2007 was followed. Ife- brown, a 
susceptible variety of cowpea used for culturing C. maculatus while Swam-1, a susceptible maize variety used for $S$. zeamais cultures were purchased from Agricultural Development Programme (ADP) office in Akure, Ondo state, Nigeria. This same variety was used for the experiment in the laboratory at temperature $28+2{ }^{\circ} \mathrm{C}$ and $75 \pm 5 \%$ relative humidity.

\subsection{Plant Powder Preparation}

Ripe fruits of Capsicum annum and Capsicum frutescens were collected from plant trees around The Federal University of Technology, Akure .The fruits were washed and sun-dried for five to ten days. Each whole dried fruits and removed seeds were pulverized to individual powder in an electric mill, sieved to pass through $1 \mathrm{~mm}^{2}$ perforations and kept in separate labelled plastic containers with tightly fitted lids kept on the laboratory work bench.

\subsection{Comparison of Insecticidal activity of plant powders}

Each fruit and seed powders of $C$. annum and C. frutescens was tested at rate of $0.0 \mathrm{~g}$ (control), $2.5 \mathrm{~g}, 5.0 \mathrm{~g}, 7.5 \mathrm{~g}$ each thoroughly mixed with $50 \mathrm{~g}$ of cowpea and $50 \mathrm{~g}$ of maize in individual $250 \mathrm{ml}$ plastic containers. Treatments were replicated four times for each experiment.

\subsection{Data analysis}

Data obtained were transformed into arcsine percentage prior analysis of variance ( ANOVA) and significantly different treatments were separated at $5 \%$ level of probability by Turkey's test.

\section{Results}

Table 1 showed cumulative effect of Capsicum frutescens seed powder against $C$. maculatus which caused 63.5\% and $73.4 \%$ mortality of bruchids at rates of $5.0 / 50 \mathrm{~g}$ and $7.5 / 50 \mathrm{~g}$ of cowpea at $24 \mathrm{hrs}$ post treatment, likewise $67.3 \%, 75.7 \%$ bruchid mortality $(5.0 / 50 \mathrm{~g}$ and $7.5 / 50 \mathrm{~g})$ at $96 \mathrm{hrs}$ respectively. This was significantly higher than $58.3 \%$ mortality obtained at $96 \mathrm{hrs}$ post treatment with Capsicum annum seed powder.No adults were killed in the control within $48 \mathrm{hrs}$ and $96 \mathrm{hrs}$. In a similar, vein in table 2 Capsicum frutescens seed powder produced $60.3 \%$ and $68.5 \%$ bruchid mortality at rates of $5.0 / 50 \mathrm{~g}$ and $7.5 / 50 \mathrm{~g}$ of maize at $24 \mathrm{hrs}$ post treatment and $63.7 \%$ and $69.3 \%$ mortality $(5.0 / 50 \mathrm{~g}$ and $7.5 / 50 \mathrm{~g})$ at $96 \mathrm{hrs}$ post-treatment. This was significantly higher than $50.4 \%$ and $57.5 \%$ $(7.5 \mathrm{~g} / 50 \mathrm{~g})$ mortality of $S$. zeamais at $48 \mathrm{hrs}$ and $96 \mathrm{hrs}$ post treatment.

A significantly lower mortality of bruchids was obtained on seeds treated with Capsicum annum and Capsicum frutescens fruit powder. No adults were killed in the control within $48 \mathrm{hrs}$ and $96 \mathrm{hrs}$ observation. This was significantly higher than $50.4 \%$ and $57.5 \%(7.5 \mathrm{~g} / 50 \mathrm{~g})$ mortality of $S$. zeamais at $48 \mathrm{hrs}$ and $96 \mathrm{hrs}$ post treatment. A significantly lower mortality of bruchids was obtained on seeds treated with Capsicum annum and Capsicum frutescens fruit powder. No adults were killed in the control within $48 \mathrm{hrs}$ and $96 \mathrm{hrs}$ observation.

\section{Discussion}

Effects of some Nigerian plant powders, extracts and oils as insect protectants have been observed in the treatment of cowpea and maize weevils (Ashamo, 2007; Lale, 1992; Oni and Ileke, 2008). Ashamo ( 2007) have reported an average mortality of $S$. zeamais at 28 days post-treatment at three rates $(0.2,0.4$ and $0.6 / 20 \mathrm{~g}$ of Capsicum frutescens/ maize seeds). It is unequivocal that seeds powders of Capsicum annum $(5.0 \mathrm{~g} / 50 \mathrm{~g})$ seeds and Capsicum frutescens at $5.0 \mathrm{~g} / 50 \mathrm{~g}$ and $7.5 \mathrm{~g} / 50 \mathrm{~g}$ seeds manifested contact insecticidal action against C.maculatus and S.zeamais in this study, this higher rates demonstrated superiority over powders from Capsicum fruits.This result is consistent with the report of Ivbijaro and Agbaje (1986): Asawalam et al.,( 2007) using Capsicum frutescens giving considerable reduction in C.maculatus infestations in all stages of development, but contradicts report by Ashamo (2007) and Yusuf et al.,(1998).

Insecticidal property of any plant material would depend on the active constituents of the plant material ( Asawalam et al., 2007). P. guineene was tested and reported to contain piperine, chavicine alkaloids (Lale, 1995). Fruit powders tested in this study was not very effective as seed powders, but significantly better than the control. Capsicum annum and Capsicum frutescens contain capsicin known to have insecticidal qualities resulting in bruchids mortality at higher rates and better protection of stored cowpea and maize seeds.

\section{Conclusion}

Capsicum frutescens and Capsicum annum have been shown to have insecticidal properties (Oni, 2009: Ivbijaro and Agbaje (1986) and justified at higher rates 5.0g, 7.5g and 5.0g/50g against stored products insects, Callosobruchus maculatus and Sitophilus zeamais in this study in effecting high percentage mortality. Capsicum frutescens and Capsicum annum are grown all over Nigeria and West African countries and its use as a safe and affordable source of insecticide may provide a sustainable alternative for pest-control in low input agriculture 
than the harzardous and expensive synthetic insecticides.

\section{References}

Adedire, C.O. \& Lajide,L.(2001).Efficacy of powders of some tropical plants in he control of pulse beetle Callosobruchus maculatus (F). Application Tropical Agriculture, 6(1), 11 - 15.

Adedire, C.O. (2001). Biology, Ecology and Control of Insect Pests of stored Cereal Grains. In: Pests of Stored Cereals and Pulses in Nigeria: Biology, Ecology and control. Edited by T.I. Ofuya and N.E.S. Lale pp. 59 - 94. Dave Collins Publications Nigeria.

Ashamo, M.O. (2007). Evaluation of Contact Toxicity and fumigant effect of some plant powders against Sitophilus zeamais (Mots). Proceedings of the Akure - Humboldt Kellong ( $3^{\text {rd }}$ SAAT annual conference: Medicinal Plants in Agriculture, The Nigeria Experience pp. 64-67.

Ivbijaro, M. F. \& Agbaje, M. (1986). Insecticidal activies of Piper guineense Schum and Thorn and Capsicum species on the cowpea bruchid, Callosobruchus maculatus F. Insect Sci. Applic., 7, 521-524.

Kling, J.A and Edmeades, G. (1997). Morphology and growth of maize-IITA/CIMMYT Research, guide 9, IITA, Ibadan, Nigeria.

Lale, N.E.S. (1992). A laboratory study of the comparative toxicity of products from three spices to the maize weevil. Postharvest Biology and Technology 2 (6): 61-64.

Lale, N.E.S. (2002). Stored Product Entomology and Acraology in Tropical Africa. Mole Publications, Maiduguri, Nigeria 204pp. Journal of Stored Product Research 38:157 - 166.

Ofuya, T. I \& Adedire, C.O. (2004). Sustainable protection of stored crops against insect depredation in the tropics 2(152-165). College Press \& Publishers Ltd, lbadan, Nigeria.

Ofuya, T.I. \& Credland, P.F. (1995). Reponses of three populations of the seed beetle. Callosobruchus maculatus (F.) (Coleoptera: Bruchidae) in selected varieties of cowpea. Vigna unguiculata (L.) Walp. Journal of Stored Products Research, 34,17 - 27

Ofuya, T.I. (2001). Biology, ecology and control of insect pests of stored legumes in Nigeria. In: Pests of stored Cereals and Pulse in Nigeria: Biology, Ecology and Control, edited by T.I. Ofuya and N.E.S. Lale, Dave Collins Publication, Nigeria pp $24-58$

Ofuya, T.I., Olotuah, O.F. \& Akinyoade,D.O. (2005).Efficacy of Eugenia aromatica powders prepared at different times in the control of Callosobruchus maculatus (Fabricius)(Coleoptera :Bruchidae) infesting stored cowpea seeds. Proceedings of the $1^{\text {st }}$ Annual Conference, School of Agricultural Technology, Akure.Nigeria, 2, $61-64$.

Ogunwolu, E.O. \& Odunlami, A.T. (1996). Suppression of seed bruchid (Callosobruchus maculatus F.) development and damage on cowpea (Vigna unguiculata (L.) Walp.) with Zanthoxyloides(lam.) Waterm. (Rutaceac) root bark powder when compared with neem seed powder and pirimiphos methyl. Crop protection, 15, 603-607.

Olotuah, O.F., Ofuya, T.I. \& Aladesanwa, R.D. (2007). Comparison of four botanical powders in the control of Callosobruchus maculatus (Fab) (Coleoptera: Bruchidae) and Sitophilus zeamais (Mots) (Coleoptera: Curculionidae). Proceedings Akure Humbolt Kellong $3^{\text {rd }}$ SAAT Annual Conf. Fed Uni. of Tech. Akure, Nigeria $16^{\text {th }}-19^{\text {th }}$ April. pp 56-59.

Oni, M.O. \& Ileke, K.D. (2008). Fumigant toxicity of four botanical plant oils on Survival, egg laying and progeny development of the dried yam beetle, Dinoderus porcellus (Lesne) (Coleoptera: Bostrichidae) Ibadan Journal of Agricultural Research, 4(2): 31-36.

Oni, M.O. (2009). Insecticidal activity of extracts from fruits of three local cultivars of pepper (Capsicum species) on cowpea seed beetle,(Callosobruchus maculatus[ Fabricius]) and maize weevil (Sitophilus zeamais (Motschulsky) ). P.hD Thesis, The Federal University of Technology, Akure.105pp

Onu, I \& Aliyu, M. (1995). Evaluation of powdered fruits of four peppers (Capsicum spp.) for the control of $C$ maculates (F) on stored cowpea seed. International Journal of Pest Management .41(3):143-145.

Oparaeke, A.M. \& Dike, M.C. (1998). Comparison of garlic (Allium sativum L.) and lemon grass (Cymbopogon citarus Staph.) products in the control of C.maculatus F.on stored cowpea. Nigerian Journal of Entomology, 13, 73-80.

Oparaeke, A.M., Dike, M.C. \& Onu, I. (1998). Evaluation of seed and leaf powders of neem (Azadirachta indica. 
A. Juss) and pirimiphos methyl for control of Callosobruchus maculatus (F) in stored cowpea. Entomological Society of Nigeria Occasional Publication, 31, 237-245.

Singh, S.R. (1997). Cowpea cultivars resistant to insect pest in world germ-plasm collection. Tropical grain legume bulletin, 19, 3-7.

$\mathrm{Su}$, H.C.F. (1984). Comparative toxicity of three pepper corn extracts to four species of stored product insects under laboratory conditions. Journal of Georgian Entomological society, 9, 190-199.

Taylor, T.A. (1971). The flight activity of Curculionidae and some other Grains infesting beetles in the field and in a store. Journal of Stored Products Research, 6, 295-306.

Yusuf, S.R. Ahmed, B.B. Chaudhary, J.P \& Yusuf, A.U. (1998). Laboratory evaluation of some plant products for the control of maize weevil (Sitophilus zeamais Mots.) in stored maize. ESN Occasional Publication, 31, 203-213.

Table 1. Effect of Capsicum annum and Capsicum frutescens on percentage mortality of Callosobruchus maculatus.

\begin{tabular}{|lccc|}
\hline \multicolumn{1}{|c}{ Treatment } & $\mathrm{g} / 50 \mathrm{~g}$ & \multicolumn{2}{c|}{$\%$ mortality } \\
& Cowpea & $48 \mathrm{hrs}$ & $96 \mathrm{hrs}$ \\
\hline Capsicum annum fruit powder & 2.5 & $10.4 \mathrm{e}$ & $18.3 \mathrm{e}$ \\
& 5.0 & $13.3 \mathrm{e}$ & $18.7 \mathrm{e}$ \\
& 7.5 & $15.4 \mathrm{e}$ & $20.4 \mathrm{e}$ \\
\hline Capsicum annum seed powder & 2.5 & $22.5 \mathrm{~d}$ & $24.7 \mathrm{e}$ \\
& 5.0 & $34.2 \mathrm{c}$ & $45.4 \mathrm{c}$ \\
Capsicum frutescens fruit powder & 7.5 & $53.4 \mathrm{~b}$ & $58.3 \mathrm{~b}$ \\
& 2.5 & $17.5 \mathrm{e}$ & $19.3 \mathrm{e}$ \\
& 5.0 & $22.2 \mathrm{~d}$ & $25.4 \mathrm{e}$ \\
\hline Capsicum frutescens seed powder & 7.5 & $25.4 \mathrm{~d}$ & $39.7 \mathrm{~d}$ \\
& 2.5 & $37.2 \mathrm{c}$ & $40.4 \mathrm{c}$ \\
& 5.0 & $63.5 \mathrm{a}$ & $67.3 \mathrm{a}$ \\
\hline Control & 7.5 & $73.4 \mathrm{a}$ & $75.7 \mathrm{a}$ \\
\hline
\end{tabular}

*Means in each column bearing the same letter (s) are not significantly different at the $5 \%$ level of probability by Turkey's test

Table 2. Effect of Capsicum annum and Capsicum frutescens on percentage mortality of Sitophilus zeamais.

\begin{tabular}{|lccc|}
\hline \multicolumn{1}{|c}{ Treatment } & $\mathrm{g} / 50 \mathrm{~g}$ & \multicolumn{2}{c|}{$\%$ mortality } \\
& maize grain & $48 \mathrm{hrs}$ & $96 \mathrm{hrs}$ \\
\hline Capsicum annum fruit powder & 2.5 & $9.5 \mathrm{e}$ & $10.3 \mathrm{e}$ \\
& 5.0 & $10.4 \mathrm{e}$ & $12.5 \mathrm{e}$ \\
& 7.5 & $11.3 \mathrm{e}$ & $14.7 \mathrm{e}$ \\
\hline Capsicum annum seed powder & 2.5 & $20.5 \mathrm{~d}$ & $25.7 \mathrm{~d}$ \\
& 5.0 & $37.3 \mathrm{c}$ & $39.3 \mathrm{c}$ \\
Capsicum frutescens fruit powder & 7.5 & $50.4 \mathrm{~b}$ & $57.5 \mathrm{~b}$ \\
\hline Capsicum frutescens seed powder & 2.5 & $13.3 \mathrm{e}$ & $15.5 \mathrm{de}$ \\
& 5.0 & $16.5 \mathrm{e}$ & $16.3 \mathrm{de}$ \\
& 7.5 & $18.4 \mathrm{e}$ & $20.7 \mathrm{~d}$ \\
\hline Control & 2.5 & $26.4 \mathrm{~d}$ & $37.5 \mathrm{c}$ \\
& 5.0 & $60.3 \mathrm{a}$ & $63.7 \mathrm{a}$ \\
& 7.5 & $68.5 \mathrm{a}$ & $63.7 \mathrm{a}$ \\
\hline
\end{tabular}

*Means in each column bearing the same letter(s) are not significantly different at the $5 \%$ level of probability by Turkey's test. 